\title{
The effects of instream barriers on the distribution of migratory marine-spawned fishes in the lower reaches of the Sundays River, South Africa
}

\author{
RJ Wasserman ${ }^{1}$, OLF Weyl ${ }^{2 *}$ and NA Strydom ${ }^{1}$ \\ ${ }^{1}$ Department of Zoology, Nelson Mandela Metropolitan University, PO Box 1600, Port Elizabeth 6000, South Africa \\ 2South African Institute for Aquatic Biodiversity (SAIAB), Private Bag 1015, Grahamstown 6140, South Africa
}

\begin{abstract}
The distribution and abundance of migratory marine-spawned fish species was investigated in the lower reaches of the warm temperate Sundays River, Eastern Cape, South Africa. Fish were collected above and below manmade instream barriers using multi-meshed gill net fleets, $12 \mathrm{~mm}$ mesh fyke nets and $1 \mathrm{~mm}$ mesh fyke nets. Sampling was undertaken twice in the winter and twice in the summer of 2009. Of the 2764 fish caught, marine-spawned species contributed $42.3 \%$. Freshwater mullet Myxus capensis and Cape moony Monodactylus falciformis were the dominant marine-spawned species at most sites and were capable of surmounting almost all instream barriers. The longitudinal distribution of these species did, however, vary by size class, with the largest individuals being recorded the furthest upstream. The longfin eel Anguilla mossambica was the only species sampled above all instream barriers, including the $4 \mathrm{~m}$ high Cleveland Weir. The giant mottled eel Anguilla marmorata was found in low numbers at sites closer to the estuary headwaters. Other marine-spawned species, including Liza tricuspidens and Mugil cephalus (Mugilidae), Argyrosomus japonicus (Sciaenidae), Lithognathus lithognathus and Rhabdosargus holubi (Sparidae), were sampled in low numbers from the site directly below the first instream barrier only, suggesting that this first barrier restricted the access of these species to upstream environments. Freshwater non-native fishes contributed $41.7 \%$ to the total catch by numbers. The potential impact of the non-native species as predators and competitors on marine-spawned species in the study area is discussed.
\end{abstract}

Keywords: migration, catadromous, eel, mullet, weir, invasive fishes

\section{Introduction}

Southern Africa has a diverse indigenous fish fauna that comprises over 2000 marine species (Smith and Heemstra, 1995) and 256 freshwater species (Skelton, 1993). Only 5 of these species are catadromous, migrating into freshwaters as larvae or juveniles, spending considerable parts of their lives in freshwater environments before returning to the marine environment as adults (Bruton et al., 1987; Whitfield, 1998). These migrating species include 3 obligatory catadromous Anguillid eels, Anguilla bicolor bicolor, Anguilla marmorata and Anguilla mossambica and 2 facultative catadromous mullets, Mugil cephalus and Myxus capensis (Whitfield, 1998). There are also numerous estuary-dependent fish species of marine-spawned origin that migrate into low salinity areas in the upper regions of estuaries at a young age to access increased feeding opportunities or to avoid predation (Miskiewicz, 1986; Strydom et al., 2003).

Instream barriers that are constructed along rivers, such as causeways, weirs and dams/impoundments, contribute to the general disturbance of the typical longitudinal nature of river systems (Jansen et al., 1999) and impede the passage of migrating fish species (Meixler et al., 2009). Globally the fragmentation of rivers has been identified as the primary driver of population decline for many migratory fishes (Masters et al., 2006). The lower reaches of rivers, in close proximity to estuarine habitats, are of particular concern. These habitats are generally overlooked because freshwater conservation priorities often lie in the upper reaches of streams and rivers (Adams et al., 2001; Abell et al., 2007). The current study therefore investigated the occurrence, abundance and extent of penetration into freshwater habitats, of both juvenile and adult marinespawned fish species, in the lower reaches of the Sundays River in the Eastern Cape of South Africa.

The lower reaches of the Sundays River are modified by an inter-basin water transfer scheme that provides water for the irrigation of dairy pastures and citrus orchards (Baird, 2001), and by the construction of numerous causeways and bridges for convenient river traversal and the construction of weirs for water abstraction. The primary aim of the current study was to determine whether these instream structures impede the upstream movement of marine-spawned fishes utilising these areas as nurseries, by quantifying their relative abundance above and below a series of potential instream barriers, between the ebb and flow region and a large weir some $49.5 \mathrm{~km}$ upstream. We hypothesised that:

- Causeway-type structures would exclude upstream movement of smaller-sized $(<50 \mathrm{~mm})$ marine-spawned fish species

- Weir-type barriers would exclude upstream movement of all marine-spawned species with the exception of anguillids.

\section{Materials and methods}

\section{Study area}

The Sundays River (Fig. 1) originates in the Karoo region of south-central South Africa and flows through the Eastern Cape 


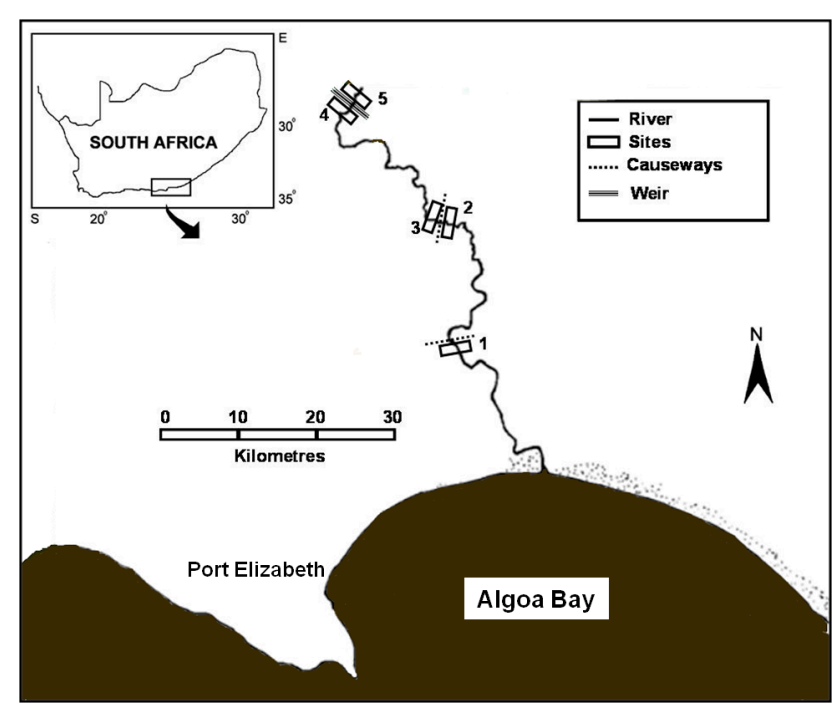

Figure 1

The geographic position of the Sundays River showing location of sampling sites

into the Indian Ocean via a permanently open estuary mouth (Beckley, 1984). The river is about $310 \mathrm{~km}$ long (Baird, 2001), with the estuary making up approximately $21 \mathrm{~km}$ of this length (Scharler and Baird, 2005). The river has a catchment size of $22063 \mathrm{~km}^{2}$ and a mean annual runoff of $29 \times 10^{6} \mathrm{~m}^{3}$ (Mackay and Schumann, 1990), with additional water supplied via an inter-basin transfer scheme from the Orange River system (Pech et al., 1995). In a survey of instream barriers, Bok (2008) identified 16 road crossings, 4 weirs and 2 dam walls between Darlington Dam and the Sundays River Estuary, all of which are potential barriers to fish migrating upstream.

\section{Field sampling and laboratory analysis}

Field sampling was conducted on the lower Sundays River between the ebb and flow region and Cleveland Weir, some $49.5 \mathrm{~km}$ upstream (Fig. 1). Within this sampling area, there are numerous potential manmade obstacles to fish migration, including 10 causeways and a low $( \pm 30 \mathrm{~cm})$ and high $( \pm 4$ m) weir (Bok, 2008) (Fig. 1). Five fixed sampling sites were selected according to their proximity to potential barriers, at various distances from the ebb and flow of the estuary. As there are 2 peak immigration periods for marine-spawned fish species into estuarine and freshwater environments (Bruton et al., 1987; Whitfield, 1998), sampling was conducted during summer and winter. Sampling was conducted in 2009, always over a new moon period (to standardise the lunar state for each field trip), in June and July for winter sampling and in November and December for summer sampling.

At each sampling site mixed passive gear sampling methods were used to sample all life-history stages of the ichthyofauna. Double-winged fine-meshed $(1 \mathrm{~mm})$ fyke nets $(\mathrm{FF})$, double-ended large $12 \mathrm{~mm}$ codend mesh fyke nets (LF) and multi-meshed gill net fleets (GN), comprising $3 \mathrm{~m}$ long $\times 2 \mathrm{~m}$ deep panels of $50 \mathrm{~mm}, 75 \mathrm{~mm}$ and $100 \mathrm{~mm}$ stretched mesh monofilament gill netting, were used.

FFs were set along the river margins facing downstream. GNs and LFs were set in the channel, parallel to the river bank. LFs were double-ended so that each net had 1 fyke opening downstream and upstream, respectively. All gear was set before sunset (between 16.00 and 18.00) and collected after sunrise
(07.00 and 10.00) the following day. On each sampling trip, 3 replicates of each gear were set once at each of the 5 sites.

On retrieval, all fish caught were identified and measured. Postflexion larvae and early juvenile fishes were measured to the nearest millimetre standard length (SL), and larger fish $(>30 \mathrm{~mm})$ were measured to the nearest millimetre total length (TL). Fish were grouped by sampling gear and all catches were expressed as catch per unit effort (CPUE) using the equation: $C P U E=C_{i} / E$, where $C_{i}$ is the total number of species $i$ caught and $E$ is the effort expended to obtain $\mathrm{C}_{i}$. For fyke nets and gill nets $E$ was expressed as an overnight net deployment session.

Salinity (PSU), temperature $\left({ }^{\circ} \mathrm{C}\right)$, dissolved oxygen $(\%)$, turbidity $(K)$ and total dissolved solids (TDS) were measured at the water surface and just above the river bed using a YSI 6600 multi-parameter probe. Water transparency was measured using a Secchi disc; Secchi depth in centimetres was converted into an extinction coefficient $(k)$ following Dawes (1981). Monthly river-flow data from the Sundays River (station number N4H001), was also acquired for 2009 (DWA, 2011).

\section{Data analysis}

CPUE data did not conform to the parametric test assumptions of normality and homogeneity of variance and therefore non-parametric tests were used for all analyses. For physical data, the Mann-Whitney $U$-test was used to test for differences between seasons and the Kruskal-Wallis $(H)$ ANOVA by ranks test was used to test for differences between sites. Spearman Rank correlations were used to determine relationships between selected CPUE of each of the sampling gear types and physico-chemical variables. A significance level of $P<0.05$ was set for all statistical tests. Margalef's species richness and Shannon-Wiener diversity indices were calculated for sampling trips, seasons and sites using the Primer statistical software package (Clarke and Warwick, 1994).

\section{Results}

\section{Environmental variability}

The physical variables measured over the study period are summarised in Fig. 2. Temperature $(U=0.00, P<0.001)$ and dissolved oxygen $(U=23.00, P<0.05)$ differed significantly between seasons, with temperature ranging from $11.7^{\circ} \mathrm{C}$ in winter to $27.2^{\circ} \mathrm{C}$ in summer and DO tending more towards saturation and super-saturation in summer than in winter. River flow (Fig. 3) was significantly lower over the winter sampling periods $(U=0.00, P<0.001)$, while salinity $(H=$ 16.63, $P<0.01)$, total dissolved solids $(H=14.93, P<0.01)$ and conductivity $(H=14.87, P<0.01)$ were significantly higher at Site 1 than at upstream sites. Volume-flow peaked during May of 2009 with winter flow values (June and July) being significantly higher $(H=59.0, P<0.001)$ than those of summer (November and December).

\section{Species composition and estuary association}

CPUE and catch by gear type is summarised in Table 1 . A total of 2764 fish, representing 11 families and 18 species, were caught during the study, with catadromous and marinespawned species comprising $42.2 \%$ of all fish caught. In terms of estuarine association, freshwater fishes (category IV) comprised the largest portion of catches in the GN (52.4\%) and LF $(62.9 \%)$ samples and the second-largest portion of 

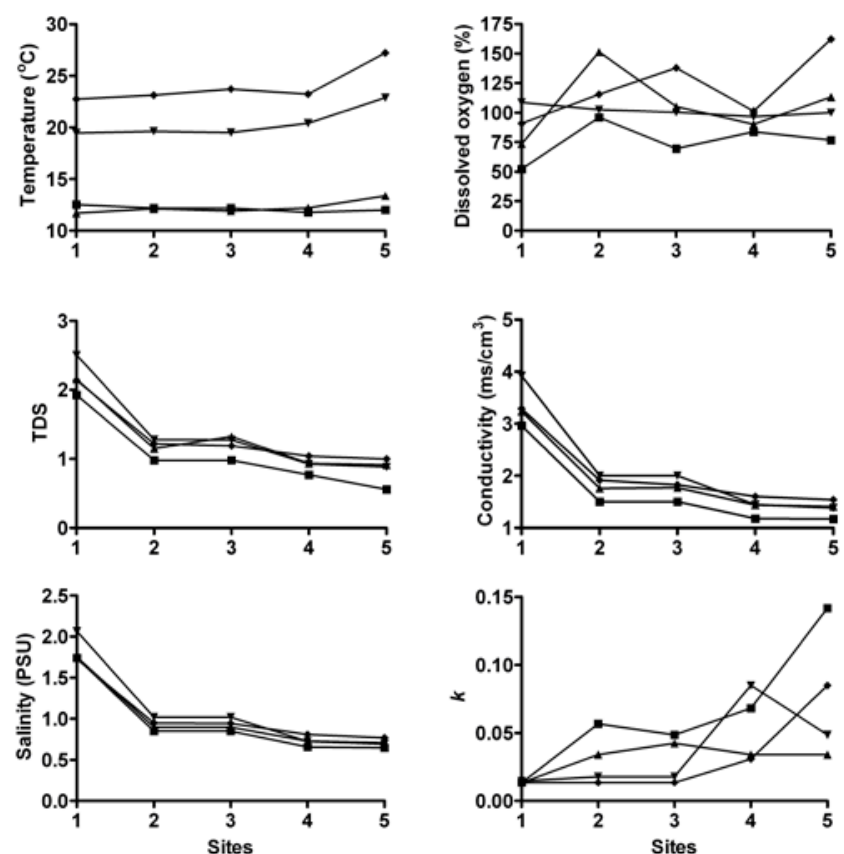

Figure 2

Temperature $\left({ }^{\circ} \mathrm{C}\right)$, dissolved oxygen (\%), total dissolved solids (TDS), conductivity $\left(\mathrm{ms} / \mathrm{cm}^{3}\right)$, salinity (PSU) and water transparency $(k)$ at each site within the Sundays River

\begin{tabular}{|c|c|c|c|}
\hline \multicolumn{4}{|c|}{$\begin{array}{c}\text { Table 1 } \\
\text { Co-ordinates of sites, the number of obstructions present } \\
\text { between sites and the distances between the ebb and flow } \\
\text { of the estuary and each site. Causeway: a road crossing } \\
\text { built across the active river channel with underlying } \\
\text { concrete culverts to allow for water flow. } \\
\text { Weir: complete concrete wall built across the active river } \\
\text { channel; Causeway: road crossing where flowing water } \\
\text { flows over or around the structure during periods of high flow. }\end{array}$} \\
\hline $\begin{array}{l}\text { No. of barriers } \\
\text { between estuary }\end{array}$ & Site & Co-ordinates of site & $\begin{array}{l}\text { Distance from } \\
\text { estuary }(\mathbf{k m})\end{array}$ \\
\hline & 1 & 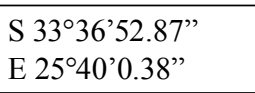 & 4.8 \\
\hline \multicolumn{4}{|l|}{5 causeways } \\
\hline & 2 & 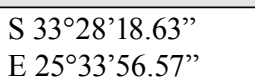 & 38.2 \\
\hline \multicolumn{4}{|l|}{1 causeway } \\
\hline & 3 & 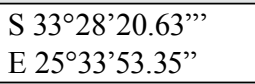 & 38.3 \\
\hline \multicolumn{4}{|c|}{3 causeways, 1 weir } \\
\hline & 4 & 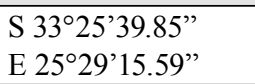 & 49.0 \\
\hline \multicolumn{4}{|c|}{1 causeways, 1 weir } \\
\hline & 5 & $\begin{array}{l}\text { S } 33^{\circ} 25^{\prime} 23.32^{\prime \prime} \\
\text { E } 25^{\circ} 28^{\prime} 52.98^{\prime \prime}\end{array}$ & 49.5 \\
\hline
\end{tabular}

FF catches (37.2\%). The catadromous species (category V) dominated FF catches, and ranked second in group dominance in the GNs. The second most dominant group caught in the LFs were the estuary-associated marine species (Category II), which contributed $21.5 \%$ to CPUE. Non-native fish species comprised $50.9 \%, 62.9 \%$ and $21.5 \%$ of GN, LF and FF catches, respectively.

Relatively few species dominated catch compositions and by number the 5 most dominant species contributed $93 \%$ to

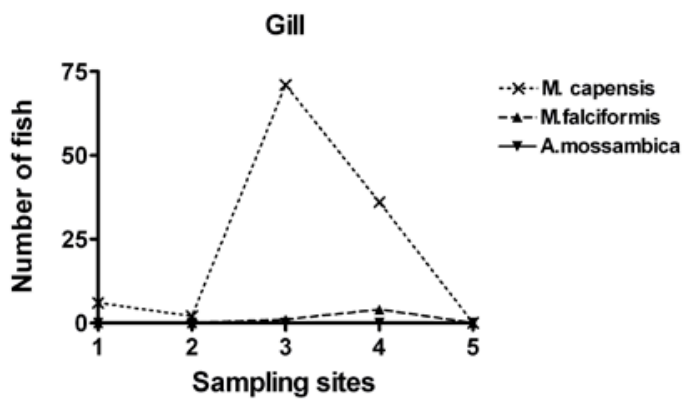

Large-meshed fyke

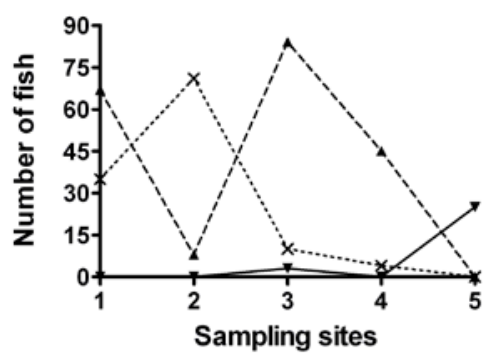

Fine-meshed fyke

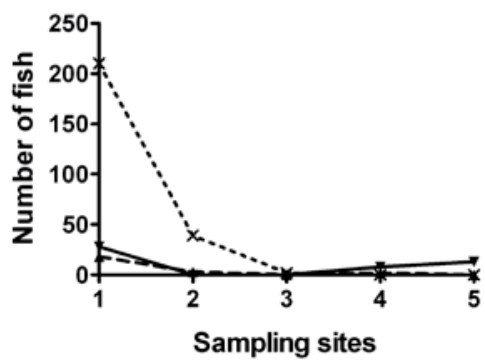

Figure 3

Total numbers of Myxus capensis, Monodactylus falciformis and Anguilla mossambica combined for 4 surveys ( $n=3$ nets $x 1$ night $x 4$ surveys) per site caught in the Sundays River, Eastern Cape during June, July, November and December 2009 for each gear type

FF, $97 \%$ to LF, and $94 \%$ to the total number of fish caught (Table 2). Oreochromis mossambicus and Myxus capensis were among the 5 most dominant species in all gears. The anguillid eels Anguilla marmorata and Anguilla mossambica were sampled exclusively in fyke nets. In both fyke net types Anguilla mossambica was among the 5 most dominant species. In FF, 2 small species, Glossogobius callidus and Barbus pallidus, also ranked among the 5 most important species. In GN and LF catches, small species were not selected for. In GNs the other 3 species were Cyprinus carpio, Clarias gariepinus and Tilapia sparmanii. In LF, T. sparmanii and Monodactylus falciformis ranked among the top 5 species.

Overall CPUE was significantly higher in summer than in winter for all gears, but there were differences between species and gear with respect to season and site. Statistical comparisons are limited to the 5 most dominant species in each gear (Table 2). The only catadromous fish species caught above the Cleveland Weir (Site 5) was A. mossambica and the species composition at this site was comprised entirely of freshwater fishes. 


\begin{tabular}{|lr|l|}
\hline \multicolumn{4}{|c|}{$\begin{array}{l}\text { Table 2 } \\
\text { Five major categories of fishes that utilise } \\
\text { southern African estuaries (Whitfield, 1994) }\end{array}$} \\
\hline Categories & Description of categories \\
\hline I & & Estuary residents. Further subdivided into: \\
\hline & Ia & Estuarine species that breed only in estuaries \\
\hline Ib & $\begin{array}{l}\text { Estuarine species that breed in estuaries and the } \\
\text { marine environment }\end{array}$ \\
\hline II & & $\begin{array}{l}\text { Estuary associated marine species. Further sub- } \\
\text { divided into: }\end{array}$ \\
\hline & IIa & $\begin{array}{l}\text { Euryhaline marine species that usually breed at } \\
\text { sea but the juveniles are dependent on estuaries as } \\
\text { nursery areas }\end{array}$ \\
\hline & IIb & $\begin{array}{l}\text { Euryhaline marine species that usually breed at } \\
\text { sea, with the juveniles occurring in estuaries but } \\
\text { also being found at sea }\end{array}$ \\
\hline & IIc & $\begin{array}{l}\text { Euryhaline marine species that usually breed at } \\
\text { sea, with the juveniles occurring in estuaries but } \\
\text { being more abundant at sea }\end{array}$ \\
\hline III & & Marine stragglers not dependent on estuaries \\
\hline IV & & Freshwater species \\
\hline V & Catadromous species \\
\hline & &
\end{tabular}

Oreochromis mossambicus and T. sparmanii CPUE was significantly higher in summer than in winter for GN and LF catches and generally decreased downstream. In FFs, which selected for small juvenile fishes, O. mossambicus CPUE was highest in winter. Cyprinus carpio CPUE showed no definite trend by season but also decreased significantly downstream, with the highest GN CPUE at Site 5. Myxus capensis CPUE was higher in winter than in summer for all gears, but this species was equally abundant throughout the system, while $T$. sparrmanii and adult $A$. mossambica CPUE was significantly higher at sites further away from the estuary and M. falciformis was absent from Cleveland Weir. FF CPUE demonstrated that Barbus pallidus (Cyprinidae) abundance decreased downstream but that juvenile $M$. capensis (29-70 mm TL) and $A$. mossambica (40-140 mm TL) CPUE was highest at the site closest to the estuary.

CPUE per sampling gear type was correlated with relevant physical variables for total fish numbers as well as for the 5 dominant species caught in each gear type (Table 3 ). Temperature correlated with most catches across all gear types, being negatively correlated with M. falciformis, M. capensis and total fish number for LF as well as with M. capensis for FF. Anguilla mossambica was the only marine-spawned species whose abundance correlated positively with distance from the estuary mouth. LF-caught M. falciformis and M. capensis were the only fish whose abundance correlated to volume of flow.

\section{Spatial trends in size composition of migratory fishes}

Myxus capensis, $M$. falciformis and A. mossambica were the dominant migrant fish species and were present in at least 4 of the 5 sites sampled and were caught in at least 2 of the 3 gears (Fig. 4). The smallest size classes $(0-70 \mathrm{~mm})$ of $M$. capensis were present in the highest numbers at the site closest to the estuary, while progressively larger individuals were sampled from upstream, with an absence of this species at Cleveland Weir (Site 5), the limit of its upstream migration capability (Fig. 5). M. capensis smaller than $50 \mathrm{~mm}$ TL were never sampled from above Site 1 . While greatly reduced in number, M. capensis larger than $70 \mathrm{~mm}$ TL were present at all sites. Similarly, the marine-spawned $M$. falciformis showed a general increase in size class and decrease in number from Site 1 to Site 4, being absent from Site 5 (Fig. 5). Monodactylus falciformis less than $50 \mathrm{~mm}$ TL were also absent from above Site 1. High numbers of the smallest size class (40-140 mm TL) of $A$. mossambica were sampled from Site 1 and were mainly in the glass-eel stage of development, although individuals as small as $64 \mathrm{~mm}$ TL were sampled from Site 5. The larger size classes of this species ( $>241 \mathrm{~mm} \mathrm{TL}$ ) were almost all sampled from Site 5 (Fig. 5).

\section{Temporal and spatial trends in species diversity}

An overall species richness $(d)$ and species diversity $\left(H^{\prime}\right)$ of 2.2 and 1.9, respectively, were obtained for combined numbers of standardised effort catch ( 3 gill nets, 3 large-meshed fyke nets and 3 fine-meshed fyke nets per site per sampling event) in the Sundays River (Table 4). Species richness was equal $(d=2.0)$ across sampled seasons, while summer species diversity was higher $\left(H^{\prime}=2.0\right)$ than that of winter $\left(H^{\prime}=1.3\right)$. Of the sampling events, January samples had the highest species richness and diversity $\left(d=2.2, H^{\prime}=2.0\right)$. June samples yielded the lowest species richness $(d=1.8)$ while June and July samples contributed equally to the lowest species diversity recorded per sampling event. Generally, species richness decreased from Site $1(d=2.0)$ to Site $5(d=1.2)$, (Table 4$)$ while species diversity increased from Site $1\left(H^{\prime}=1.3\right)$ to Site $4\left(H^{\prime}=1.9\right)$. At the presence/absence level, Site 1 contributed up to $46.7 \%$ more species than any other site overall (Fig. 6).

\section{Discussion}

The lower Sundays River is altered by the presence of a water transfer scheme developed to provide water for irrigation in the Sundays River valley. The resultant impact on the river is expressed by the low seasonal variation in $\mathrm{pH}$, conductivity and turbidity. Temperature and dissolved oxygen differed

\begin{tabular}{|l|c|c|c|c|}
\hline \multicolumn{5}{|c|}{$\begin{array}{c}\text { Rable 3 } \\
\text { Range of physico-chemical parameters between } \\
\text { sampling trips in the Sundays River in 2009 }\end{array}$} \\
\cline { 2 - 5 } & \multicolumn{2}{|c|}{ Winter } & \multicolumn{2}{c|}{ Summer } \\
\cline { 2 - 5 } Physical parameter & June & July & December & January \\
\hline Temperature $\left({ }^{\circ} \mathrm{C}\right)$ & $12.5-11.8$ & $13.4-11.7$ & $22.9-19.5$ & $27.2-22.8$ \\
\hline Salinity $($ PSU) & $1.7-0.7$ & $1.8-0.7$ & $2.1-0.7$ & $1.7-0.8$ \\
\hline Dissolved oxygen $(\%)$ & $95.9-52.3$ & $151.4-73.4$ & $108.7-96.5$ & $162.1-90.9$ \\
\hline Total dissolved solids & $1.9-0.6$ & $2.2-0.9$ & $2.5-0.9$ & $2.1-1.0$ \\
\hline Conductivity $\left(\mathrm{ms} / \mathrm{cm}^{3}\right)$ & $3.0-1.2$ & $3.2-1.4$ & $3.9-1.4$ & $3.3-1.5$ \\
\hline Turbidity $(k)$ & $0.14-0.01$ & $0.04-0.01$ & $0.09-0.01$ & $0.09-0.01$ \\
\hline
\end{tabular}




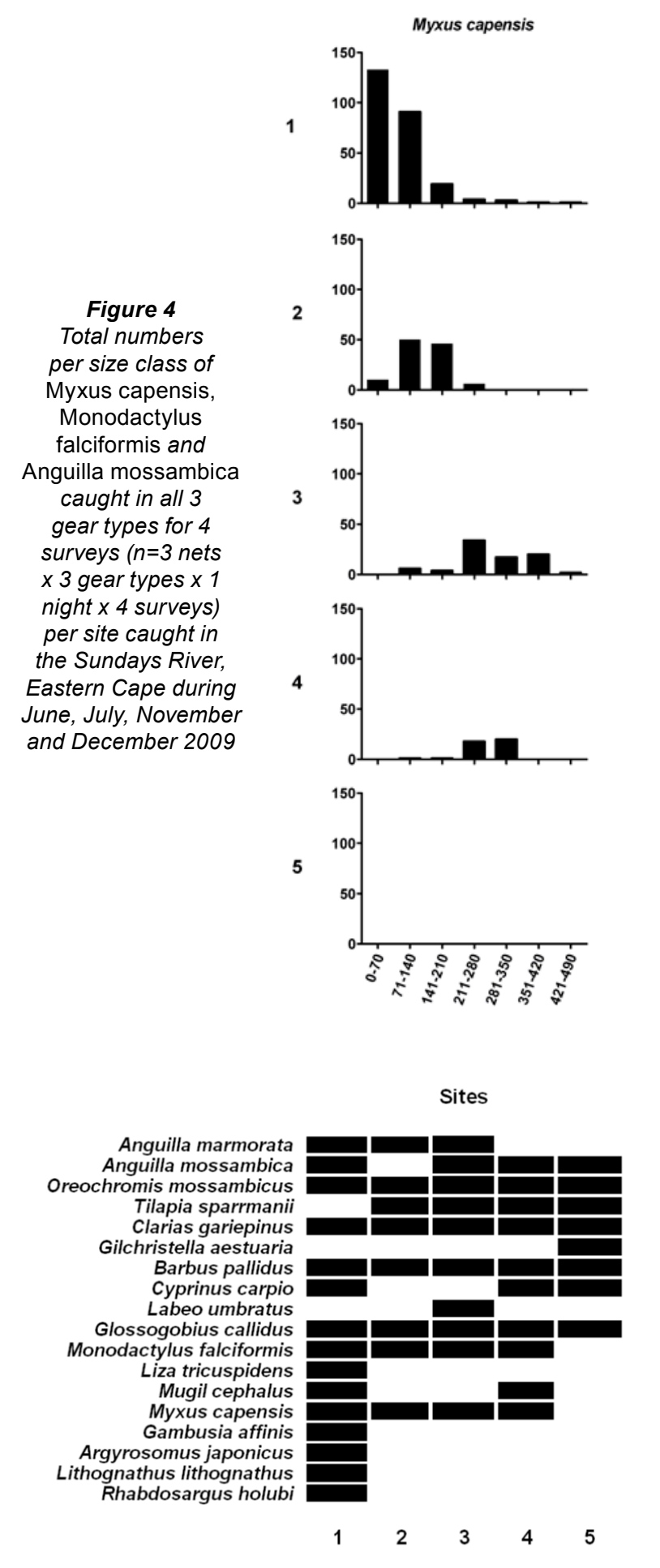

Figure 5

Overall presence and absence of all species per site in the Sundays River

significantly between seasons and this was correlated with elevated summer species richness and abundance of certain species, namely juvenile eel, A. mossambica (Anguillidae) and river goby, G. callidus (Gobiidae).

Summer catches of $A$. mossambica were dominated by the glass-eel stage of development, the migrations of which typically peak during summer months (Bruton et al., 1987). Likewise, G. callidus larvae increase in numbers in Eastern Cape estuaries during summer months after spring spawning
Monodactylus falciformis
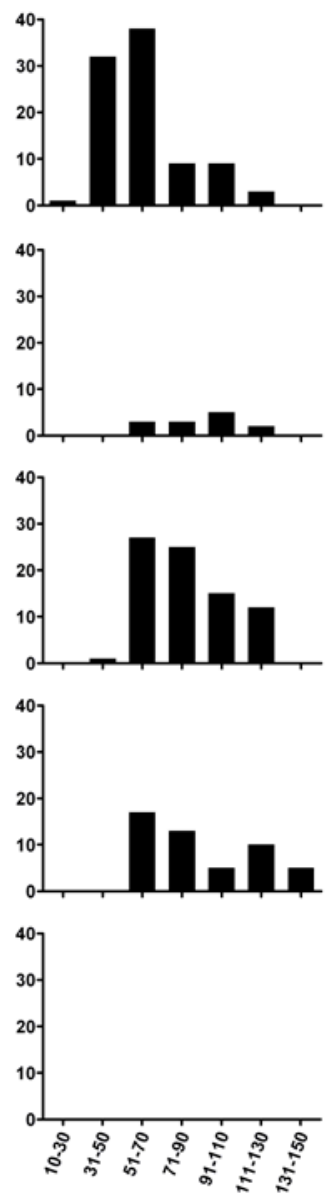

Size classes $(\mathrm{mm})$

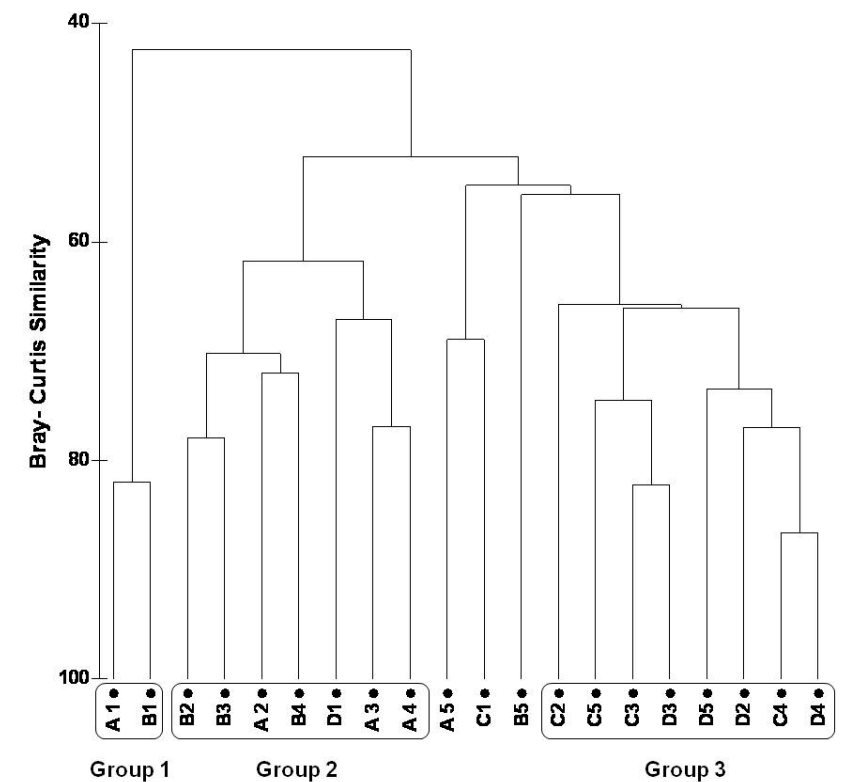

Figure 6

Bray-Curtis similarity dendrogram showing percentage similarity of total standardised effort catch samples in the Sundays River over the duration of the study. Each sample is represented by a 2-letter code, the first being the sampling event code ( $A=$ June, $B=J u l y, C=$ November, $D=$ December $)$ and the second being the site code (1=Site1, 2=Site 2, 3=Site 3, 4=Site 4, 5=Site 5) 
Table 4

Gill net species composition, winter and summer catch per unit effort (fish per net night), standard length, total number of individuals in all samples (No.), percentage composition of total catch by number (\%) and estuary association after Whitfield (1994) combined for 4 surveys ( $n=3$ nets $x 1$ night $x 5$ sites $x 4$ surveys) conducted in the Sundays River, Eastern Cape during June, July, November and December 2009.

\begin{tabular}{|c|c|c|c|c|c|c|c|c|}
\hline \multirow[t]{2}{*}{ Family } & \multirow[t]{2}{*}{ Species } & \multicolumn{2}{|c|}{ Mean CPUE (Range) } & \multicolumn{2}{|c|}{ Body length (mm) } & \multirow[t]{2}{*}{ No. } & \multirow[t]{2}{*}{$\%$} & \multirow{2}{*}{$\begin{array}{c}\text { Estuarine } \\
\text { association }\end{array}$} \\
\hline & & Winter & Summer & Mean & Range & & & \\
\hline \multirow{2}{*}{ Cichlidae } & Oreochromis mossambicus & $0.06(0-2)$ & $0.80(0-6)$ & 222.7 & $128-421$ & 77 & 28.95 & IV \\
\hline & Tilapia sparrmanii & $0.02(0-2)$ & $0.44(0-11)$ & 141.4 & $123-175$ & 42 & 15.79 & IV \\
\hline Clariidae & Clarias gariepinus & $0.07(0-2)$ & $0.02(0-1)$ & 554.9 & $450-630$ & 8 & 3.01 & IV \\
\hline \multirow{2}{*}{ Cyprinidae } & Cyprinus carpio & $0.30(0-1)$ & $0.06(0-2)$ & 255.7 & $165-337$ & 9 & 3.20 & IV \\
\hline & Labeo umbratus & $9.04(0-2)$ & 0 & 389.2 & $335-423$ & 4 & 1.50 & IV \\
\hline Monodactylidae & Monodactylus falciformis & $0.02(0-1)$ & $0.05(0-3)$ & 114.8 & $100-139$ & 7 & 2.44 & IIa \\
\hline \multirow{2}{*}{ Mugillidae } & Mugil cephalus & 0 & $0.01(0-1)$ & 246.0 & $246-246$ & 1 & 0.38 & IIa \\
\hline & Myxus capensis & $0.90(0-10)$ & $0.38(0-6)$ & 304.7 & $220-447$ & 115 & 43.23 & $\mathrm{Vb}$ \\
\hline Sciaenidae & Argyrosomus japonicus & 0 & $0.04(0-1)$ & 417.0 & $280-473$ & 4 & 1.50 & III \\
\hline
\end{tabular}

\section{Table 5}

Large-meshed fyke net species composition, winter and summer catch per unit effort (fish per net night), standard length, total number of individuals in all samples (No.), percentage composition of total catch by number (\%) and estuary association after Whitfield (1994) combined for 4 surveys ( $n=3$ nets $x 1$ night $\times 5$ sites $\times 4$ surveys) conducted in the Sundays River, Eastern Cape during June, July, November and December 2009.

\begin{tabular}{|c|c|c|c|c|c|c|c|c|}
\hline \multirow[t]{2}{*}{ Family } & \multirow[t]{2}{*}{ Species } & \multicolumn{2}{|c|}{ Mean CPUE (Range) } & \multicolumn{2}{|c|}{ Body length (mm) } & \multirow[t]{2}{*}{ No. } & \multirow[t]{2}{*}{$\%$} & \multirow{2}{*}{$\begin{array}{c}\text { Estuary } \\
\text { association }\end{array}$} \\
\hline & & Winter & Summer & Mean & Range & & & \\
\hline \multirow{2}{*}{ Anguillidae } & Anguilla marmorata & 0 & $0.17(0-4)$ & 937.0 & $105-1370$ & 10 & 0.98 & $\mathrm{Va}$ \\
\hline & Anguilla mossambica & $0.18(0-3)$ & $0.28(0-4)$ & 498.0 & $320-740$ & 28 & 2.75 & $\mathrm{Va}$ \\
\hline \multirow{2}{*}{ Cichlidae } & Oreochromis mossambicus & $7.22(0-79)$ & $0.95(0-13)$ & 115.5 & $54-273$ & 489 & 47.99 & IV \\
\hline & Tilapia sparrmanii & $0.12(0-3)$ & $0.25(0-42)$ & 99.8 & $56-184$ & 142 & 13.94 & IV \\
\hline Clariidae & Clarias gariepinus & $0.03(0-1)$ & $0.10(0-3)$ & 483.8 & $262-855$ & 8 & 0.78 & IV \\
\hline Cyprinidae & Cyprinus carpio & $0.03(0-1)$ & 0 & 216.5 & $210-223$ & 2 & 0.20 & IV \\
\hline Gobiidae & Glossogobius callidus & $0.03(0-1)$ & 0 & 99.0 & $99-99$ & 2 & 0.20 & $\mathrm{Ib}$ \\
\hline Monodactylidae & Monodactylus falciformis & $2.85(0-52)$ & $0.58(0-10)$ & 79.8 & $20-145$ & 206 & 20.22 & IIa \\
\hline \multirow{2}{*}{ Mugillidae } & Liza tricuspidens & $0.02(0-1)$ & 0 & 116.0 & $116-116$ & 1 & 0.10 & IIb \\
\hline & Myxus capensis & $1.98(0-46)$ & 0 & 149.5 & $91-350$ & 119 & 11.68 & $\mathrm{Vb}$ \\
\hline \multirow{2}{*}{ Sparidae } & Lithognathus lithognathus & $0.02(0-1)$ & 0 & 114.0 & $114-114$ & 1 & 0.10 & IIa \\
\hline & Rhabdosargus holubi & $0.03(0-1)$ & $0.15(0-2)$ & 108.5 & $85-149$ & 11 & 1.10 & IIa \\
\hline
\end{tabular}

(Strydom and Neira, 2006). Myxus capensis and M. falciformis numbers were dissimilar across sites, being absent from the uppermost site, Site 5, and found in highest numbers at Site 1. This site (Site 1) is situated directly below a causeway and was the only site uninterrupted by instream barriers between marine and freshwater environments. Five marine-spawned fish species that were not caught further upstream were also sampled from this site. The absence of these estuarine-dependent species and reduction in M. capensis and M. falciformis CPUE above this first instream barrier suggests that this causeway impedes fish movement and may be a bottleneck that separates estuarine fishes from catadromous migrants.

The culverts allowing water to flow underneath the causeways increase the velocity of the water flow $(> \pm 1.5 \mathrm{~m} / \mathrm{s})$, hindering and even preventing fish from passing through (Bok, 2008). The swimming and jumping abilities of fish are largely dependent on body length. In swimming trial experiments, Bok et al. (2007) showed that $M$. capensis $<50 \mathrm{~mm}$ TL generally could not outswim current velocities of $1.5 \mathrm{~m} / \mathrm{s}$. In the present study, of the species assessed for length differences across sites, smaller size classes dominated below the first barrier (Site 1) and were largely absent above it. This result is consistent with Meixler et al. (2009), where smaller-sized fish were thought to be most affected by barriers owing to their weaker darting speeds and jumping abilities. Site 4 , situated just below the $3 \mathrm{~m}$ high Cleveland Weir, produced larger size classes of M. capensis and M. falciformis. These species were however absent from Site 5, a few hundred meters further upstream, showing that this $4 \mathrm{~m}$ high weir is excluding all upstream-migrating fishes, except $A$. mossambica, from further utilising additional freshwater habitats in the Sundays River. The fish fauna of Cleveland Weir itself (Site 5) was dominated by various non-native fishes and the anguillid, A. mossambica. Anguilla mossambica was the only species of marine-spawned origin for which adults (> $241 \mathrm{~mm} \mathrm{TL}$ ) were more abundant above the large weir separating Site 4 from Site 5 than in sites below it. Eels are known to migrate considerable distances as elvers. In the Sabi-Lundi River system of Zimbabwe, for example, $87 \mathrm{~mm}$ TL $A$. mossambica have been recorded $290 \mathrm{~km}$ upstream from the ocean (Jubb, 1964). During these migrations elvers are able to traverse significant instream barriers facilitated by their ability to creep up vertical wet surfaces (Legault, 1988). In the Sundays River, this allows access to upstream regions where Jubb (1960) and Weyl et al. (2009) reported the presence of $A$. mossambica upstream of the $48 \mathrm{~m}$ high Darlington Dam wall, some 104 $\mathrm{km}$ inland. However, instream barriers potentially impose age-dependent migration restrictions, as older anguillids of larger size classes are unable to climb steep vertical surfaces (Cairns et al., 2004). 


\begin{tabular}{|c|c|c|c|c|c|c|c|c|}
\hline \multicolumn{9}{|c|}{$\begin{array}{l}\text { Table } 6 \\
\text { Small-meshed fyke net species composition, winter and summer catch per unit effort (fish per net night), standard } \\
\text { length, total number of individuals in all samples (No.), percentage composition of total catch by number (\%) and } \\
\text { estuary association after Whitfield (1994) combined for } 4 \text { surveys }(n=3 \text { nets } \times 1 \text { night } x 5 \text { sites } \times 4 \text { surveys) conducted } \\
\text { in the Sundays River, Eastern Cape during June, July, November and December } 2009 \text {. }\end{array}$} \\
\hline \multirow[t]{2}{*}{ Family } & \multirow[t]{2}{*}{ Species } & \multicolumn{2}{|c|}{ Mean CPUE (Range) } & \multicolumn{2}{|c|}{ Body length (mm) } & \multirow[t]{2}{*}{ No. } & \multirow[t]{2}{*}{$\%$} & \multirow{2}{*}{$\begin{array}{c}\text { Estuary } \\
\text { association }\end{array}$} \\
\hline & & Winter & Summer & Mean & Range & & & \\
\hline \multirow{2}{*}{ Anguillidae } & Anguilla marmorata & $0.07(0-1)$ & $0.07(0-1)$ & 224.5 & $54-680$ & 4 & 0.27 & $\mathrm{Va}$ \\
\hline & Anguilla mossambica & $0.20(0-3)$ & $1.38(0-24)$ & 176.8 & $46-540$ & 48 & 3.22 & $\mathrm{Va}$ \\
\hline \multirow{2}{*}{ Cichlidae } & Oreochromis mossambicus & $6.27(0-140)$ & $1.42(0-27)$ & 81.4 & $13-745$ & 231 & 15.62 & IV \\
\hline & Tilapia sparrmanii & $0.03(0-1)$ & $2.40(0-35)$ & 85.9 & $26-136$ & 74 & 5.01 & IV \\
\hline Clariidae & Clarias gariepinus & $0.07(0-1)$ & $0.25(0-2)$ & 170.3 & $64-325$ & 10 & 0.64 & IV \\
\hline Clupeidae & Gilchristella aestuaria & $0.27(0-4)$ & $0.05(0-1)$ & 39.2 & $32-57$ & 10 & 0.64 & Ia \\
\hline \multirow{2}{*}{ Cyprinidae } & Barbus pallidus & $0.93(0-5)$ & $6.78(0-37)$ & 49.1 & $20-73$ & 232 & 15.68 & IV \\
\hline & Cyprinus carpio & 0 & $0.07(0-1)$ & 26.3 & $18-37$ & 2 & 0.14 & IV \\
\hline Gobiidae & Glossogobius callidus & $0.63(0-4)$ & $7.82(0-48)$ & 54.8 & $15-97$ & 254 & 17.18 & $\mathrm{Ib}$ \\
\hline Monodactylidae & Monodactylus falciformis & $0.63(0-7)$ & $0.13(0-2)$ & 62.3 & $32-116$ & 23 & 1.56 & IIa \\
\hline \multirow{3}{*}{ Mugillidae } & Liza tricuspidens & $0.07(0-1)$ & 0 & 120.0 & $87-153$ & 2 & 0.14 & $\mathrm{IIb}$ \\
\hline & Mugil cephalus & $0.03(0-1)$ & $0.10(0-2)$ & 67.3 & $39-114$ & 4 & 0.27 & IIa \\
\hline & Myxus capensis & $16.3(0-27)$ & $3.17(0-72)$ & 74.5 & $29-232$ & 548 & 39.57 & $\mathrm{Vb}$ \\
\hline Poeciliidae & Gambusia affinis & 0 & $0.03(0-1)$ & 28.0 & $28-28$ & 1 & 0.07 & IV \\
\hline
\end{tabular}

\begin{tabular}{|c|c|c|c|c|c|}
\hline \multicolumn{6}{|c|}{$\begin{array}{c}\text { Table } 7 \\
\begin{array}{c}\text { Significant differences between seasons (winter } n=10, \text { summer } n=10) \\
\text { and between sites }(n=20) \text { for ranked numerically dominant species and } \\
\text { total catch per gear type in the Sundays River }\end{array}\end{array}$} \\
\hline \multirow[t]{2}{*}{ Gear type } & \multirow[t]{2}{*}{ Species } & \multicolumn{2}{|c|}{ Seasons } & \multicolumn{2}{|c|}{ Sites } \\
\hline & & $U$ & $P$ & $\mathrm{H}$ & $P$ \\
\hline \multirow{6}{*}{ Gill nets } & Myxus capensis & & - & 39.21 & +++ \\
\hline & Oreochromis mossambicus & 192.00 & ++++ & 9.80 & + \\
\hline & Tilapia sparrmanii & 254.00 & +++ & 10.67 & + \\
\hline & Cyprinus carpio & & - & 13.58 & ++ \\
\hline & Clarias gariepinus & & - & 15.40 & ++ \\
\hline & Total catch & 305.50 & + & 29.41 & +++ \\
\hline \multirow{6}{*}{$\begin{array}{l}\text { Large-mesh fyke } \\
\text { nets }\end{array}$} & Oreochromis mossambicus & 286.00 & + & 17.97 & ++ \\
\hline & Tilapia sparrmanii & 232.50 & +++ & 14.12 & ++ \\
\hline & Monodactylus falciformis & 277.50 & ++ & 14.39 & ++ \\
\hline & Myxus capensis & 225.00 & ++++ & & - \\
\hline & Anguilla mossambica & & - & 30.81 & +++ \\
\hline & Total catch & 282.00 & + & 9.54 & + \\
\hline \multirow{6}{*}{$\begin{array}{l}\text { Fine-mesh fyke } \\
\text { nets }\end{array}$} & Myxus capensis & & - & 22.65 & +++ \\
\hline & Glossogobius callidus & 80.50 & +++ & & - \\
\hline & Barbus pallidus & 252.00 & ++++ & 19.42 & +++ \\
\hline & Oreochromis mossambicus & & - & 19.19 & +++ \\
\hline & Anguilla mossambica & 295.00 & +++ & 14.17 & ++ \\
\hline & Total catch & 271.50 & ++++ & 19.55 & ++++ \\
\hline $\begin{array}{ll}+ & P<0.05 \\
++ & P<0.01 \\
+++ & P<0.001 \\
- & P>0.05\end{array}$ & & & & & \\
\hline
\end{tabular}

CPUE of large (211-358 mm TL) M. capensis in GN were fairly evenly distributed through the river, albeit at low abundance. This was not the case, however, for juvenile M. capensis $(<71 \mathrm{~mm} \mathrm{TL})$ and $M$. falciformis ( $<31 \mathrm{~mm}$ TL) CPUE from fyke nets, which correlated with numerous parameters, including a negative relationship with distance from the estuary. The overall reduction in $M$. capensis and $M$. falciformis numbers upstream could be a result of barrier effects, although migrating species are expected to be less abundant further upstream, as many should find suitable habitat along the way.
Non-native fishes comprised $39.6 \%$ of all fish caught in the study. Marine-spawned fish migrating into freshwater do so to access increased feeding opportunities, possibly under reduced competition and predation in freshwater environments (Bruton et al., 1987). Non-native fishes may potentially reduce beneficial aspects found under natural-state conditions through competition and predation. Small aquatic insects and zooplankton, for example, are important food sources for juveniles of both native species, such as A. mossambica (Bruton et al., 1987), M. falciformis (Whitfield, 1985) and M. capensis 


\begin{tabular}{|c|c|c|c|c|c|c|c|c|}
\hline \multicolumn{9}{|c|}{ 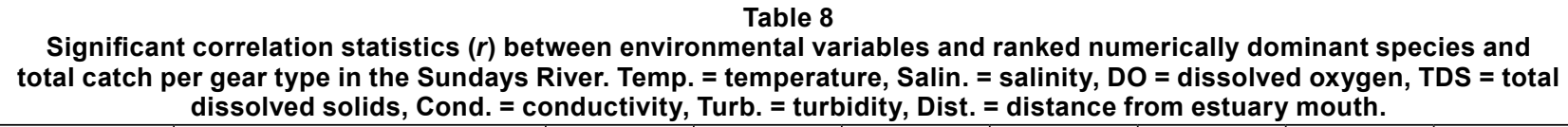 } \\
\hline Gear type & Species & Temp. & Salin. & DO & TDS & Cond. & Turb. & Dist. \\
\hline \multirow{6}{*}{ Gill nets } & Myxus capensis & - & - & - & - & - & - & - \\
\hline & Oreochromis mossambicus & 0.54 & - & 0.27 & - & - & - & - \\
\hline & Tilapia sparrmanii & 0.53 & -0.30 & - & -0.27 & - & - & - \\
\hline & Cyprinus carpio & & -0.33 & - & -0.26 & -0.26 & 0.28 & 0.42 \\
\hline & Clarias gariepinus & - & -0.27 & - & -0.29 & -0.30 & - & - \\
\hline & Total catch & - & - & - & - & - & - & 0.32 \\
\hline \multirow{6}{*}{$\begin{array}{l}\text { Large-mesh } \\
\text { Fyke nets }\end{array}$} & Oreochromis mossambicus & -0.37 & - & -0.52 & - & - & - & - \\
\hline & Tilapia sparrmanii & 0.54 & -0.27 & - & - & - & - & 0.37 \\
\hline & Monodactylus falciformis & -0.42 & - & -0.40 & - & - & - & -0.30 \\
\hline & Myxus capensis & -0.51 & - & -0.28 & - & - & - & -0.31 \\
\hline & Anguilla mossambica & - & -0.41 & - & -0.36 & -0.35 & 0.36 & 0.57 \\
\hline & Total catch & -0.37 & - & -0.44 & - & - & - & - \\
\hline \multirow{6}{*}{$\begin{array}{l}\text { Small-mesh } \\
\text { Fyke nets }\end{array}$} & Myxus capensis & -0.27 & 0.45 & -0.30 & 0.40 & 0.41 & -0.33 & -0.57 \\
\hline & Glossogobius callidus & 0.69 & - & 0.49 & - & - & - & - \\
\hline & Barbus pallidus & 0.53 & -0.42 & 0.27 & -0.38 & -0.32 & 0.29 & 0.55 \\
\hline & Oreochromis mossambicus & - & - & -0.33 & - & - & - & - \\
\hline & Anguilla mossambica & 0.34 & - & - & - & - & 0.31 & - \\
\hline & Total catch & 0.37 & 0.26 & - & 0.27 & 0.33 & -0.26 & - \\
\hline
\end{tabular}

\begin{tabular}{|c|c|c|c|c|c|c|}
\hline \multicolumn{7}{|c|}{$\begin{array}{c}\text { Table } 9 \\
\begin{array}{c}\text { Number of species caught in each gear type, overall species richness and overall diversity indices of } \\
\text { combined standardised effort catch for sites, seasons and sampling trips of the Sundays River }\end{array}\end{array}$} \\
\hline & & \begin{tabular}{|l|} 
No. of species, \\
Fine-mesh fyke
\end{tabular} & $\begin{array}{l}\text { No. of species, } \\
\text { Large-mesh } \\
\text { fyke }\end{array}$ & $\begin{array}{l}\text { No. of species, } \\
\text { Gill net }\end{array}$ & $\begin{array}{c}\text { Combined } \\
d\end{array}$ & $\underset{H^{\prime}}{\text { Combined }}$ \\
\hline Overall & & 14 & 12 & 9 & 2.2 & 1.9 \\
\hline \multirow{2}{*}{ Season } & Winter & 12 & 11 & 7 & 2.0 & 1.3 \\
\hline & Summer & 13 & 7 & 8 & 2.0 & 2.0 \\
\hline \multirow{4}{*}{ Sampling event } & June & 11 & 8 & 5 & 1.9 & 1.2 \\
\hline & \begin{tabular}{|l|} 
July \\
\end{tabular} & 7 & 10 & 6 & 2.0 & 1.2 \\
\hline & November & 10 & 7 & 6 & 1.9 & 1.9 \\
\hline & December & 12 & 7 & 8 & 2.2 & 2.0 \\
\hline \multirow{5}{*}{ Site } & 1 & 12 & 8 & 4 & 2.0 & 1.3 \\
\hline & 2 & 8 & 5 & 2 & 1.2 & 1.5 \\
\hline & 3 & 5 & 7 & 6 & 1.6 & 1.7 \\
\hline & 4 & 8 & 7 & 6 & 1.5 & 1.9 \\
\hline & 5 & 8 & 5 & 3 & 1.2 & 1.6 \\
\hline
\end{tabular}

(Whitfield, 1998), and non-native fishes, such as Gambusia affinis (Mansfield and McCardle, 1998), O. mossambicus (Bruton and Boltt, 1975) and T. sparmanii (Skelton, 1993), which are common in the Sundays River. Predation of marinespawned fishes in freshwater environments by large non-native predatory fish such as Clarias gariepinus (Bruton, 1979) is also likely. In highly disturbed systems such as the Sundays River, the impact of non-native fishes on the indigenous ichthyofauna is difficult to isolate from other anthropogenic impacts such as the construction of instream barriers, habitat alteration and pollution. Unfortunately, there were insufficient data to fully investigate and isolate confounding effects. Future research is therefore necessary to assess the direct and indirect impacts of non-native fishes on native ichthyofaunal and invertebrate communities.

Two major barriers to the upstream movement of fish seem to be present in the Sundays River, the first being the causeway closest to the estuary, which appears to exclude many fish from further upstream penetration. The second barrier is that of the Cleveland Weir, excluding certain marine-spawned species from the river above the obstruction.

The results of the study therefore support the first hypothesis that causeway-type structures act as barriers to fish smaller than $50 \mathrm{~mm}$ TL. Numerous $M$. falciformis, $M$. capensis and A. mossambica smaller in TL than $50 \mathrm{~mm}$ were caught below the first causeway. No marine-spawned fish less than $50 \mathrm{~mm}$ TL were sampled from above this barrier, and, in addition, certain estuarine species were completely absent upstream of Site 1.

The second hypothesis, that weir-type barriers would exclude upstream movement of all marine-spawned species with the exception of anguillids, was only partially supported. The low weir situated downstream of Site 4 did not exclude any of the marine-spawned species present at Site 3, and therefore does not act as a total migration barrier. This could be attributed to weir inundation during periods of increased 


\begin{tabular}{|c|c|c|c|c|c|}
\hline \multicolumn{6}{|c|}{$\begin{array}{c}\text { Table } 10 \\
\text { SIMPER test results for combined standardised effort catch, comparing } \\
\text { differences between (Vs.) sites and seasons, listing dominant species } \\
\text { driving community differences between groups. Oreochromis } \\
\text { mossambicus }=\text { O.m., Tilapia sparrmanii }=\text { T.s., Barbus pallidus }=\text { B.p., } \\
\text { Glossogobius callidus }=\text { G.c., Monodactylus falciformis }=\text { M.f., } \\
\text { Myxus capensis = M.c. }\end{array}$} \\
\hline Vs. & 1 & 2 & 3 & 4 & Summer \\
\hline 2 & $\begin{array}{c}\text { O.m. }(25.2) \\
\text { M.c. }(20.4) \\
\text { T.s. }(11.8)\end{array}$ & & & & \\
\hline 3 & $\begin{array}{c}\text { M.c. }(25.7) \\
\text { O.m. }(23.5) \\
\text { T.s. }(5.6)\end{array}$ & $\begin{array}{c}\text { M.f. (18.9) } \\
\text { T.s. (16.3) } \\
\text { O.m. (15.3) }\end{array}$ & & & \\
\hline 4 & $\begin{array}{c}\text { M.c. }(25.1) \\
\text { O.m. }(18.4) \\
\text { T.s. }(13.5) \\
\end{array}$ & $\begin{array}{l}\text { M.c. }(28.7) \\
\text { O.m. (12.8) } \\
\text { M.f. (11.5) }\end{array}$ & $\begin{array}{l}\text { T.s. }(16.8) \\
\text { O.m. (16.4) } \\
\text { B.p. (12.7) }\end{array}$ & & \\
\hline 5 & $\begin{array}{l}\text { O.m. }(20.2) \\
\text { M.c. }(14.8) \\
\text { M.f. }(13.0)\end{array}$ & $\begin{array}{l}\text { M.c. }(20.6) \\
\text { O.m. }(18.1) \\
\text { B.p. }(13.1)\end{array}$ & $\begin{array}{l}\text { M.c. }(20.8) \\
\text { M.f. }(18.9) \\
\text { B.p. }(13.1)\end{array}$ & $\begin{array}{l}\text { O.m. (14.3) } \\
\text { M.c. (14.1) } \\
\text { M.f. (16.2) }\end{array}$ & \\
\hline Winter & & & & & $\begin{array}{c}\text { T.s. }(18.5) \\
\text { M.c. }(15.6) \\
\text { G.c. }(13.4)\end{array}$ \\
\hline
\end{tabular}

flow, thereby allowing migration of weak-swimming fish over or around such barriers, although no large flooding events were recorded on the Sundays River over the 2008/2009 period (DWA, 2011). The larger, $4 \mathrm{~m}$ high Cleveland Weir, however, excluded all marine-spawned species except A. mossambica. The absence of A. marmorata from this site may either be a result of an inability to traverse the instream barrier or may be a result of their lower regional abundance when compared to A. mossambica (Bruton et al., 1987 ) or their affinity for the lower regions of rivers closer to estuaries (Jubb, 1960).

Globally, river fragmentation is considered the primary cause for migratory fish population declines (Masters et al., 2006) and often contributes to unnatural homogenous fish assemblages upstream of barriers (Guenther and Spacie, 2006). Instream barriers such as the causeways and weirs on the Sundays River potentially cut off many kilometres of suitable habitat and may increase mortality rates of migrating fish (Bok, 1983). In the barrier-free Great Kei River, for example, Bok (1980) recorded M. capensis as far as $173 \mathrm{~km}$ upstream of the estuary. In addition to the instream barrier-effects, the large impoundments such as Darlington Dam and the Cleveland Weir of the Sundays River reduce downstream flood peaks, ultimately affecting upstream movement by migrating fishes over and around smaller obstacles during such events. If migration routes are to be re-established for the diadromous fishes of the Sundays River, the removal, modification or replacement of instream barriers with migration-friendly alternatives, as well as the construction of fishways across these barriers, should be considered.

\section{Acknowledgements}

This work is based on financial support from the National Research Foundation, South Africa. Any opinion, findings and conclusions or recommendations expressed in this material are those of the authors and therefore the NRF does not accept any liability in regard thereto. Tanja van de Ven, Bevan O' Reilly, Wilbert Kadye, Adrian Evans, Daniel Miller, Tim Vink, and
Mary-Anne Roux are thanked for their field assistance. Colin Biggs, Steve and management of Dunbrody Estates and Bob Maske are also thanked for permission to access sampling sites on their properties. Gratitude is also extended to the Sundays River Irrigation Board who facilitated access to various sites. We also thank 2 anonymous reviewers for their comments.

\section{References}

ABELL R, ALLAN JD and LEHNER B (2007) Unlocking the potential of protected areas for freshwater. Biol. Cont. 134 48-63.

ADAMS SB, FRISSEL CA and RIEMAN BE (2001) Geography of invasion in mountain streams: consequences of headwater lake fish introductions. Ecosystems 4 (4) 296-307.

BAIRD D (2001) Sundays River Estuary, Algoa Bay, Eastern Cape. In Dupra V, Smith SV, Marshall Crossland JI and Crossland CJ (eds.) Estuarine Systems of Sub-Saharan Africa: Carbon, Nitrogen and Phosphorous Fluxes. LOICZ Reports \& Studies No. 18. LOICZ, Texel, The Netherlands.

BECKLEY LE (1984) The ichthyofauna of the Sundays Estuary, South Africa, with particular reference to the juvenile marine component. Estuaries 7 (3) 248-258.

BOK AH (1983) The demography, breeding biology and management of two mullet species (Pisces: Mugilidae) in the eastern Cape, South Africa. Ph.D. thesis, Rhodes University, Grahamstown. $268 \mathrm{pp}$.

BOK AH (2008) Obstacles to migration and proposed location and design of fishways and barriers to migration. In: Sundays River Freshwater Fish Research Project Report No. 3. 61 pp.

BOK AH, KOTZE P, HEATH R, and ROSSOUW J (2007) Guidelines for Planning, Design and Operation of Fishways in South Africa. WRC Report No. TT 287/07. Water Research Commission, Pretoria.

BRUTON MN, BOK AH and DAVIES MTT (1987) Life history styles of diadromous fishes in inland waters of southern Africa. Am. Fish. Soc. Symp. 1 104-121.

BRUTON MN and BOLTT RE (1975) Aspects of the biology of Tilapia mossambica Peters (Pisces: Cichlidae) in a natural freshwater lake (Lake Sibaya, South Africa). J. Fish Biol. 7 423-445.

CAIRNS DK, SHIAO JC, IIZUKA Y, TZENG WN and MACPHERSON CD (2004) Movement patterns of American eels in an impounded watercourse, as indicated by otolith microchemistry. N. Am. J. Fish Manage. 24 452-458. 
CLARKE KR and WARWICK RM (1994) Change in Marine Communities: An Approach to Statistical Analysis and Interpretation. Plymouth Marine Laboratory, Plymouth. 144 pp.

CLAVERO M and GARCIA-BERTHOU E (2005) Invasive species are a leading cause of animal extinctions. Trends Ecol. Evol. 20 (30) 110.

DAWES CJ (1981) Marine Botany. John Wiley and Sons, New York.

DWA (DEPARTMENT OF WATER AFFAIRS, SOUTH AFRICA) (2011) Hydrological Services: Surface water flow data: Station Data N4H001. URL: www.dwaf.gov.za/hydrology/cgi-bin/his/cgihis.exe/ StationInfo? Station $=\mathrm{n} 4 \mathrm{H} 001$ (Accessed 26 May 2011).

GUENTHER CB and SPACIE A (2006) Changes in fish assemblage structure upstream of impoundments with the upper Wabash River Basin, Indiana. Trans. Am. Fish. Soc. 135 570-583.

JANSEN W, KAPPUS B, BOHMER J and BEITER T (1999) Fish communities and migrations in the vicinity of fishways in a regulated river (Enz, Baden-Wurttemborg, Germany). Limnologica 29 425-435.

JUBB RA (1960) Elvers and post-elvers of the freshwater eels of South Africa. Piscator 49 68-76.

JUBB RA (1964) The eels of South African rivers and observations on their ecology. In: Davies DHS (ed.) Ecological studies in Southern Africa. Junk, Den Haag, Holland. 186-206.

LEGAULT A (1998) Le franchissement des barrages par l'escalade de l'angille: étude an Sévre Niortaise. Bull. Fr. Péche Piscic. 308 1-10.

LEPRIEUR F, BEAUCHARD O, BLANCHET S, OBERDORFF T and BROSSE S (2008) Fish invasions in the world's river systems: when natural processes are blurred by human activities. PLoS Biol. 6 (2) 0404-0410.

MACKAY HM and SCHOEMAN EH (1990) Mixing and circulation in the Sundays River Estuary. Est. Coast Shelf Sci. 31 203-216.

MANSFIELD S and McCARDLE BH (1998) Dietary composition of Gambusia affinis (Family Poeciliidae) populations in the northern Waikato region of New Zealand. N. Z. J. Mar. Freshwater Res. 32 (3) $375-383$

MASTERS JEG, JANG MH, HA K, BIRD PD, FREAR PA and LUCAS MC (2006) The commercial exploitation of a protected anadromous species, the river lamprey (Lampetra fluviatilis (L.)), in the tidal River Ouse, north-east England. Aquatic Conservation: Mar. Freshwater Ecosyst. 16 77-92.

MEIXLER MS, BAIN MB and WALTER MT (2009) Predicting barrier passage and habitat suitability for migratory fish species. Ecol. Model. 220 2782-2791.

MISKIEWICZ AG (1986) The season and length of entry into a temperate Australian estuary of the larvae of Acanthopagrus aus tralis, Rhabdosargus sarba and Chrysophrys auratus (Teleostei: Sparidae). In: Uyeno T, Arai R, Taniuchi T and Matsuura K (eds.) Indo-Pacific Fish Biology. Ichthyological Society of Japan, Tokyo. 740-747.

MORITA K and YAMAMOTO S (2002) Effects of habitat fragmentation by damming on the persistence of stream-dwelling charr populations. Cons. Biol. 16 1318-1323.
PECH GA, McCOURT B and KEMPER NP (1995) Orange River development project, replanning study. Environmental overview of the Eastern Cape Rivers. Department of Water Affairs and Forestry, Ninham Shand Incorporated Report No. 2357, Cape Town, South Africa.

REVEILLAC E, GAGNAIRE PA, LECOMTE-FINIGERS P, ROBINET T, VALADE P and FEUNTEUN E (2009) Development of a key using morphological characters to distinguish south-western Indian Ocean anguillid glass eels. J. Fish Biol. 74 2171-2177.

ROLLS RJ (2010) The role and location of barriers to migration in the spatial distribution and conservation of fish assemblages in a coastal river system. Biol. Cons. doi: 10.1016/j.biocon.2010.09.011.

SCHARLER UM and BAIRD D (2005) A comparison of selected ecosystem attributes of three South African estuaries with different freshwater inflow regimes, using network analysis. J. Mar. Sys. 56 283-308.

SKELTON PH (1993) A Complete Guide to the Freshwater Fishes of Southern Africa. Southern Book Publishers, Halfway House. 395 pp.

SMITH MM and HEEMSTRA PC (1995) Smiths' Sea Fishes. Macmillan, Johannesburg, South Africa. $1047 \mathrm{pp}$

STRYDOM NA, WHITFIELD AK and WOOLDRIDGE TH (2003) The role of estuarine type in characterizing early stage fish assemblages in warm temperature estuaries, South Africa. Afr. Zool. 38 (1) $29-43$.

STRYDOM NA and NEIRA FJ (2006) Description and ecology of Glossogobius callidus and Redigobius dewaalii (Gobiidae) from temperate South African estuaries. Afr. Zool. 41 (2) 240-251.

TRAAS GRL (2009) The conservation and management of freshwater fishes in the Greater Addo Elephant National Park. M.Sc. Thesis, Rhodes University, Grahamstown. 157 pp.

VAN DER ELST RP and WALLACE JH (1976) Identification of the juvenile mullet of the east coast of South Africa. J. Fish Biol. 9 371-374.

WEYL OLF and LEWIS H (2006) First record of predation by the alien invasive freshwater fish Micropterus salmoides on migrating estuarine fishes in South Africa. Afr. Zool. 41 (2) 294-296.

WEYL OLF, BOOTH AJ, WINKER H, MCCAFFERTY J, WARTENBERG R, PEEL R AND TRAAS GRL (2009) Task 3: Assessment of the fishery potential for alien species on Darlington Dam. In: Sundays River Freshwater Fish Research Project. Report No. 5. $57 \mathrm{pp}$.

WHITFIELD AK (1985) The role of zooplankton in the feeding ecology of fish fry from some southern African estuaries. S. Afr. J. Zool. 20 166-171.

WHITFIELD AK (1994) An estuary-associated classification for the fishes of southern Africa. S. Afr. J. Sci. 90 411-417.

WHITFIELD AK (1998) Biology and Ecology of Fishes in South African estuaries. Ichthyological Monographs of the J.L.B. Smith Institute of Ichthyology. $223 \mathrm{pp}$. 